\begin{tabular}{|l|l|l||}
\hline \multicolumn{2}{|c|}{ PublisherInfo } \\
\hline \hline PublisherName & $:$ & BioMed Central \\
\hline \hline PublisherLocation & $:$ & London \\
\hline \hline PublisherImprintName & $:$ & BioMed Central \\
\hline \hline
\end{tabular}

\title{
WAS protein and phagocytosis
}

\begin{tabular}{|l|l|l||}
\hline \multicolumn{2}{|c|}{ ArticleInfo } \\
\hline \hline ArticleID & $:$ & 106 \\
\hline \hline ArticleDOI & $:$ & $10.1186 /$ ar-2001-67994 \\
\hline \hline ArticleCitationID & $:$ & 67994 \\
\hline \hline ArticleSequenceNumber & $:$ & 63 \\
\hline \hline ArticleCategory & $:$ & Paper Report \\
\hline \hline ArticleFirstPage & $:$ & 1 \\
\hline \hline ArticleLastPage & $:$ & 3 \\
\hline \hline & & RegistrationDate $: 2001-6-8$ \\
ArticleHistory & $:$ & Received \\
& Accepted 2001-7-25 & $:$ 2001-7-25 \\
& & OnlineDate \\
\hline \hline ArticleCopyright & $:$ & Biomed Central Ltd2001 \\
\hline \hline ArticleGrants & $:$ & \\
\hline \hline
\end{tabular}




\begin{tabular}{|l|l|l|l|}
\hline ArticleContext & $:$ & 130753311 \\
\hline
\end{tabular}

Sylvie Fournel, ${ }^{\text {Aff1 }}$

Aff1 CNRS, Strasbourg, France

Keywords

Apoptosis, phagocytosis, WASp

\section{Context}

Clearance of apoptotic cells by macrophages is an important physiological phenomenon as it provides a mechanism for eliminating apoptotic bodies without inducing inflammation. The inhibition of this clearance has been described as an initiator of lupus disease. Wiskott-Aldrich syndrome (WAS) protein (WASp) is expressed on hematopoietic cells that are able to transduce signals from membrane receptors to the actin cytoskeleton. This molecule is implicated in actin relocalization during IgG-mediated phagocytosis. To investigate this further, the authors have studied phagocytosis of apoptotic cells in WASp-deficient mice.

\section{Significant findings}

As for IgG-opsonized targets, ingestion of apoptotic cells was impaired in WASp-deficient macrophages in vitro and remained significantly below levels achieved by normal macrophages after $120 \mathrm{~min}$. While the binding of apoptotic cells to macrophages remained similar, engulfment was inhibited. Similar to the results from in vitro studies, phagocytosis of apoptotic cells in vivo was clearly decreased in WASp-deficient mice when compared to that in normal mice.

\section{Comments}

A role for WASp in phagocytosis and more precisely in apoptotic cell clearance provides new insights into understanding the susceptibility of WAS patients to autoimmune disease ( $\sim 40 \%$ of WAS patients develop autoimmune disease). Moreover, further studies of the WASp gene, analysis of WASp 
modifications or investigations of anti-WASp antibodies in lupus patients or in lupus-prone mice may now be indicated.

\section{Methods}

WASp deficient mice; quantification of phagocytosis: carboxyfluorescein diacetate succinimidyl ester staining, streptavidin staining, incubation with macrophages

\section{Additional information}

\section{References}

1. Leverrier Y, Lorenzi R, Blundell MP, Brickell P, Kinnon C, Ridley AJ, Thrasher AJ: Cutting edge: The Wiskott-Aldrich syndrome protein is required for efficient phagocytosis of apoptotic cells. J

Immunol. 2001, 166: 4831-4834.

This PDF file was created after publication. 